JOURNAL OF MIDWIFERY CARE :

VOL. 01 NO. 01, DESEMBER 2020

DOI: $10.34305 / \mathrm{JMC} . \mathrm{V} 1 \mathrm{I} 1.197$
Ciptaan disebarluaskan di bawah

Lisensi Creative Commons Atribusi-

NonKomersial-BerbagiSerupa 4.0

Internasional.

\title{
PERBEDAAN TINGKAT KECUKUPAN NUTRISI DAN PEMBERIAN ASI PADA \\ BALITA STUNTING DAN TIDAK STUNTING DI DESA SUKAMUKTI WILAYAH KERJA UPTD PUSKESMAS JALAKSANA
}

\author{
Siti Nunung Nurjannah \\ Stikes Kuningan \\ sitinunung.nurjannah@gmail.com
}

\begin{abstract}
Abstrak
Kurangnya asupan zat gizi dapat menyebabkan stunting. Prevalensi stunting di Indonesia 27,67\% pada tahun 2019 (Riskesdas, 2019) sedangkan di Kabupaten Kuningan 42\% salah satunya Kecamatan Jalaksana Desa Sukamukti terdapat 20 balita sangat pendek dan 115 balita pendek. Penelitian ini bertujuan untuk mengetahui perbedaan tingkat kecukupan nutrisi dan pemberian ASI pada balita stunting dan tidak stunting di Desa Sukamukti Wilayah Kerja UPTD Puskesmas Jalaksana Tahun 2020. Jenis penelitian comparative study dengan desain cross sectional. Populasi 241 balita, menggunakan teknik Proportionate Stratified Random Sampling jumlah sampel yaitu 150 responden. Analisis data menggunakan uji Mann Whitney. Sebagian besar balita memiliki kecukupan nutrisi dalam kategori normal sebanyak 118 responden (78,7\%), diberikan ASI secara eksklusif sebanyak 93 responden (62\%), tidak stunting sebanyak 79 responden $(52,7 \%)$. Terdapat perbedaan kecukupan nutrisi ( $\mathrm{p}$ value $=$ 0,001) dan pemberian ASI ( $p$-value=0,002) pada balita stunting dan tidak stunting. Kesimpulan terdapat perbedaan kecukupan nutrisi dan pemberian ASI pada balita stunting dan tidak stunting, diharapkan dapat meningkatkan pemberian ASI dan porsi makanan yang bergizi supaya tidak terjadi stunting.
\end{abstract}

Kata kunci $\quad$ : Kecukupan Nutrisi, Pemberian ASI, Stunting Balita

\section{Pendahuluan}

Masa balita merupakan usia penting untuk tumbuh kembang secara fisik. Pertumbuhan anak pada usia balita sangat pesat sehingga memerlukan asupan zat gizi yang sesuai dengan kebutuhan balita. Asupan zat gizi tidak memenuhi kebutuhan balita maka dapat berakibat kurang gizi (Proverawati, 2013). Kurangnya asupan zat gizi dapat menyebabkan beberapa masalah gizi, salah satunya yaitu stunting. Stunting 
JOURNAL OF MIDWIFERY CARE :

VOL. 01 NO. 01, DESEMBER 2020

DOI: $\underline{10.34305 / J M C . V 1 I 1.197}$

adalah kurangnya energi protein jangka panjang yang ditandai kurangnya tinggi badan menurut umur (Sundari et al., 2015).

Stunting menjadi masalah serius dalam pertumbuhan dan perkembangan balita di dunia. World Health Organization (WHO) menetapkan batas toleransi stunting maksimal 20 persen atau seperlima dari jumlah keseluruhan balita. Prevalensi stunting di beberapa negara di Asia Tenggara, seperti Myanmar sebesar $35 \%$, Vietnam sebesar $23 \%$ dan Thailand $16 \%$. Sementara, di Indonesia tercatat 7,8 juta dari 23 juta balita adalah penderita stunting atau sekitar 35,6\% dengan rincian sebanyak $18,5 \%$ kategori sangat pendek dan $17,1 \%$ kategori pendek. Prevalensi stunting di Indonesia mengalami penurunan dari $30,8 \%$ tahun 2018 menjadi 27,67\% pada tahun 2019 (Riskesdas, 2019).

Berdasarkan data prevalensi stunting pada balita di Jawa Barat sebesar 29,9\%. Terdapat tiga belas Kabupaten di Jawa Barat yang melampaui angka menurut WHO yaitu melampaui angka lebih dari $20 \%$ diantaranya Kabupaten Garut sebesar 43,2\%, Kabupaten Cirebon 42,47\%, Kabupaten Kuningan 42\%, Kabupaten Sumedang 41,08\%, Kabupaten Bandung 40,7\%, Kabupaten Subang 40,47\%, Kabupaten Sukabumi 37,6\%, Kabupaten
Ciptaan disebarluaskan di bawah

Lisensi Creative Commons Atribusi-

NonKomersial-BerbagiSerupa 4.0

Internasional.

Indramayu 36,12\%, Kabupaten Cianjur 35,7\%, Kabupaten Bandung Barat 34,2\%, Kabupaten Karawang 34,87\%, Kabupaten Tasikmalaya 33,3\%, Kabupaten Bogor 28,29\%, (Riskesdas, 2019).

World Health Organization menguraikan penyebab stunting secara langsung dan tidak langsung. Secara langsung, penyebab kependekan berkaitan dengan empat faktor utama yaitu penyakit infeksi, praktik menyusui, ketersediaan makanan, serta lingkungan rumah tangga dan keluarga. Sementara secara tidak langsung, penyebab kependekan adalah faktor komunitas dan sosial yaitu ekonomi politik, kesehatan dan pelayanan kesehatan, pendidikan, sosial dan kebudayaan, pertanian dan sistem makanan, air, sanitasi dan lingkungan, (Sundari et al., 2015).

Stunting sendiri dapat berdampak pada keberlangsungan seumur hidup, artinya keadaan ini tidak dapat diperbaiki dan akan mengganggu perkembangan otak, lemahnya sistem imun, besarnya risiko terhadap penyakit diabetes dan kanker pada masa dewasa. Anak perempuan yang stunting akan tumbuh menjadi wanita yang kekurangan gizi, saat mengandung bayi tidak mendapat asupan gizi yang cukup dan keadaan ini akan terulang kembali (Danefi, 2019) 
JOURNAL OF MIDWIFERY CARE :

VOL. 01 NO. 01, DESEMBER 2020

DOI: $\underline{10.34305 / J M C . V 1 I 1.197}$

Pemerintah telah memiliki program resmi untuk menangani masalah stunting seperti pada Peraturan Presiden No. 42 Tahun 2013 tentang Gerakan Nasional Percepatan Perbaikan Gizi berikut empat program pemerintah untuk mencegah stunting yaitu 1. Peningkatan Gizi Masyarakat melalui program Pemberian Makanan Tambahan (PMT) untuk meningkatkan status gizi anak, 2.Sanitasi Berbasis Lingkungan melalui peningkatan kualitas sanitasi lingkungan di 250 desa pada 60 Kabupaten/Kota dengan target prioritas pada desa yang tingkat prevalensi stunting tinggi. 3. Anggaran setiap desa dalam program ini sebesar 100 juta dengan target minimal $20 \mathrm{KK}$ terlayani jamban individu sehat, cuci tangan pakai sabun dan kebijakan yang menyasar kepada warga miskin agar ada perubahan perilaku. 4. Pembangunan infrastruktur air minum dan sanitasi untuk meningkatkan kualitas hidup manusia salah satunya mencegah stunting.

Kabupaten Kuningan menjadi salah satu kabupaten yang menyumbang angka stunting terbanyak ketiga di Jawa Barat yaitu sekitar 42\%, (Riskesdas, 2018) Beberapa Kecamatan penyumbang stunting terbanyak di Kabupaten Kuningan diantaranya Kecamatan Cidahu, Kecamatan Luragung, Kecamatan Cigandamekar,
Ciptaan disebarluaskan di bawah

Lisensi Creative Commons Atribusi-

NonKomersial-BerbagiSerupa 4.0

Internasional.

Kecamatan Jalaksana, Kecamatan Japara, Kecamatan Selajambe. (Dinas Kesehatan Kabupaten Kuningan, 2019). Sementara itu di Kecamatan Jalaksana, berdasarkan data dari Puskesmas Jalaksana Tahun 2019 terdapat total 20 balita dalam kategori sangat pendek dan 115 balita dalam kategori pendek, 10 balita dalam kategori gizi buruk dan 102 balita dalam kategori gizi kurang.

Berdasarkan hasil studi pendahuluan pada tanggal 05 maret 2020 di Kecamatan Jalaksana terdapat 4 desa yang mengalami kejadian stunting, salah satu nya berada di Desa Sukamukti terdapat 1 balita dalam kategori gizi buruk dan 18 balita dalam kategori gizi kurang, 2 balita dalam kategori sangat pendek dan 6 balita dalam kategori pendek. Hasil wawancara terhadap 6 ibu yang memiliki balita di Desa Sukamukti, didapatkan informasi seluruh ibu memberikan asi eksklusif kepada anaknya. Namun dalam pemberian nutrisi pada balita masih kurang, ibu mengaku bahwa sering menyediakan sarapan pagi dengan membeli bubur ayam, biskuit, nasi uduk, anak sering diberikan jajanan yang kurang bergizi seperti chiki, minuman susu kental manis dan variasi jenis makanan tambahan kurang dengan jumlah tidak menentu. Sementara menurut Depkes, (2009) kebutuhan makanan sehari yang seharusnya 
JOURNAL OF MIDWIFERY CARE :

VOL. 01 NO. 01, DESEMBER 2020

DOI: $10.34305 / \mathrm{JMC} . \mathrm{V} 1 \mathrm{I1} .197$

dikonsumsi balita adalah nasi sebanyak 1-3 piring, lauk 2-3 potong, sayur 1-1,5 mangkok dan buah 2-3 potong.

Stunting pada anak usia dibawah lima tahun biasanya kurang disadari karena perbedaan anak yang stunting dengan anak yang normal pada usia tersebut tidak terlalu dilihat. Usia di bawah lima tahun merupakan periode emas dalam menentukan kualitas sumber daya manusia yang dilihat dari segi pertumbuhan fisik maupun kecerdasan, sehingga hal ini harus didukung oleh status gizi yang baik. Anak yang mengalami stunting pada masa ini cenderung sulit mencapai tinggi badan optimal pada periode selanjutnya. Berdasarkan hal tersebut, maka
Ciptaan disebarluaskan di bawah

Lisensi Creative Commons Atribusi-

NonKomersial-BerbagiSerupa 4.0 Internasional.

peneliti tertarik untuk melakukan penelitian yang berjudul "Perbedaan Tingkat Kecukupan Nutrisi dan Pemberian ASI Pada Balita Stunting dan Tidak Stunting di Desa Sukamukti Wilayah Kerja UPTD Puskesmas Jalaksana Tahun 2020”.

\section{Metode}

Metode penelitian yang digunakan adalah . Jumlah comparative study populasi 241 responden, jumlah sampel 150 responden menggunakan teknik Proportionate Stratified Random Sampling, dengan kriteria inklusi dan eksklusi. Analisis data menggunakan analisis bivariat.

\section{Hasil}

Tabel 1. Distribusi Frekuensi Kecukupan Nutrisi Balita

\begin{tabular}{ccc}
\hline Kecukupan Nutrisi & Frekuensi (f) & Persentase (\%) \\
\hline Buruk & 0 & 0,0 \\
Kurang & 30 & 20,0 \\
Normal & 118 & 78,7 \\
Lebih & 2 & 1,3 \\
Total & $\mathbf{1 5 0}$ & $\mathbf{1 0 0}$ \\
\hline
\end{tabular}

Berdasarkan tabel 1, dapat dijelaskan dari 150 balita yang diteliti sebagian besar kecukupan nutrisi dalam kategori normal yaitu sebanyak 118 responden $(78,7 \%)$.

Tabel 2. Distribusi Frekuensi Pemberian ASI Pada Balita

\begin{tabular}{ccc}
\hline ASI & Frekuensi (f) & Persentase (\%) \\
\hline Tidak Eksklusif & 57 & 38,0 \\
Eksklusif & 62 & 62,0 \\
Total & $\mathbf{1 5 0}$ & $\mathbf{1 0 0}$ \\
\hline
\end{tabular}

Berdasarkan tabel 2, dapat dijelaskan dari 150 balita yang diteliti, sebagian besar mendapatkan ASI eksklusif yaitu sebanyak 93 responden (62,0\%). 
JOURNAL OF MIDWIFERY CARE :

VOL. 01 NO. 01, DESEMBER 2020

DOI: $10.34305 / \mathrm{JMC} . \mathrm{V} 1 \mathrm{I} 1.197$
Ciptaan disebarluaskan di bawah

Lisensi Creative Commons Atribusi-

NonKomersial-BerbagiSerupa 4.0

Tabel 3. Distribusi Frekuensi Stunting Pada Balita

\begin{tabular}{ccc}
\hline Stunting & Frekuensi (f) & Persentase (\%) \\
\hline Stunting & 71 & 47,3 \\
Tidak Stunting & 79 & 52,7 \\
Total & $\mathbf{1 5 0}$ & $\mathbf{1 0 0}$ \\
\hline
\end{tabular}

Berdasarkan tabel 3 di atas, dari 150 responden yang diteliti, lebih dari setengahnya dalam kategori tidak stunting yaitu sebesar 79 responden $(52,7 \%)$.

Tabel 4. Hasil Analisis Perbedaan Kecukupan Nutrisi Pada Balita Stunting dan Tidak Stunting

\begin{tabular}{cccccccc}
\hline \multirow{2}{*}{$\begin{array}{c}\text { Kecukupan } \\
\text { Nutrisi }\end{array}$} & \multicolumn{4}{c}{ Stunting } & \multicolumn{2}{c}{ Total } & \multirow{2}{*}{ p-Value } \\
\cline { 2 - 5 } & $\mathrm{N}$ & $\%$ & $\mathrm{~N}$ & $\%$ & $\mathrm{~N}$ & $\%$ & \\
\hline Kurang & 25 & 83,3 & 5 & 16,7 & 30 & 100 & \\
Normal & 46 & 55,9 & 72 & 62,1 & 118 & 100 & 0,001 \\
Lebih & 0 & 0,0 & 2 & 100,0 & 2 & 100 & \\
Total & $\mathbf{7 1}$ & $\mathbf{4 7 , 3}$ & $\mathbf{7 9}$ & $\mathbf{5 2 , 7}$ & $\mathbf{1 5 0}$ & $\mathbf{1 0 0}$ & \\
\hline
\end{tabular}

Berdasarkan tabel 4 di atas dapat dijelaskan dari 118 responden yang memiliki kecukupan nutrisi normal, sebagian besar tidak mengalami stunting yaitu sebanyak 72 responden $(62,1 \%)$. Dari 30 responden dengan kecukupan nutrisi kurang, sebagian besar responden mengalami stunting yaitu sebanyak 25 responden (83,3\%). Pada responden dengan kecukupan nutrisi lebih, seluruhnya tidak mengalami stunting $(100 \%)$.

Berdasarkan hasil Mann Whitney didapatkan nilai $\mathrm{p}$-value $=0,001$ lebih kecil dari $\square=0,05$ sehingga dapat diputuskan bahwa Ha diterima artinya ada perbedaan status gizi pada balita stunting dan tidak stunting di Desa Sukamukti Kabupaten Kuningan.

Tabel 5. Hasil Analisis Perbedaan Pemberian ASI Pada Balita Stunting dan Tidak Stunting

\begin{tabular}{|c|c|c|c|c|c|c|c|}
\hline \multirow{3}{*}{ ASI } & \multicolumn{4}{|c|}{ Stunting } & \multirow{2}{*}{\multicolumn{2}{|c|}{ Total }} & \multirow{3}{*}{ p-value } \\
\hline & \multicolumn{2}{|c|}{ Stunting } & \multicolumn{2}{|c|}{ Tidak Stunting } & & & \\
\hline & $\mathrm{N}$ & $\%$ & $\mathrm{~N}$ & $\%$ & $\mathrm{~N}$ & $\%$ & \\
\hline Tidak Eksklusif & 36 & 63,2 & 21 & 36,8 & 57 & 100 & \\
\hline Eksklusif & 35 & 37,6 & 58 & 63,4 & 93 & 100 & 0,002 \\
\hline Total & 71 & 47,3 & 79 & 52,7 & 150 & 100 & \\
\hline
\end{tabular}

Berdasarkan tabel 5 di atas dapat dijelaskan bahwa dari 57 responden ASI tidak eksklusif sebagian besar mengalami stunting yaitu sebanyak 36 responden 
JOURNAL OF MIDWIFERY CARE :

VOL. 01 NO. 01, DESEMBER 2020

DOI: $\underline{10.34305 / J M C . V 1 I 1.197}$

$(63,2 \%)$ dan dari 93 responden ASI eksklusif sebagian besar tidak mengalami stunting yaitu sebanyak 58 responden $(63,4 \%)$. Berdasarkan hasil Mann Whitney didapatkan nilai $\mathrm{p}$-value $=0,002$ lebih kecil dari $\square=0,05$ sehingga dapat diputuskan bahwa Ha diterima artinya ada perbedaan pemberian ASI pada balita stunting dan tidak stunting di Desa Sukamukti Kabupaten Kuningan.

\section{Pembahasan}

\section{Gambaran Kecukupan Gizi Pada Balita}

Berdasarkan hasil penelitian di Desa Sukamukti dapat dijelaskan dari 150 balita yang diteliti sebagian besar kecukupan nutrisi dalam kategori gizi normal yaitu sebanyak 118 responden $(78,7 \%), 30$ responden (20\%) dalam kategori gizi kurang dan 2 responden $(1,3 \%)$ dalam kategori gizi lebih.

Balita merupakan masa penting pertumbuhan anak. Asupan zat gizi melalui makanan pada periode ini akan menentukan pertumbuhan dan perkembangan di masa yang akan datang. Menurut WHO, (2017) malnutrisi dan infeksi memiliki kaitan yang erat. Siklus malnutrisi dan infeksi seperti sebuah lingkaran. Infeksi menyebabkan tubuh membutuhkan lebih banyak energi, yang dapat menginduksi malnutrisi jika
Ciptaan disebarluaskan di bawah

Lisensi Creative Commons Atribusi-

NonKomersial-BerbagiSerupa 4.0

Internasional.

kebutuhan akan asupan energi tidak terpenuhi.Sebaliknya malnutrisi dapat menyebabkan immunodeficiency yang akan memperburuk episode penyakitnya. Selain itu immunodeficiency menyebabkan host lebih rentan terkena infeksi. Hal tersebut dapat menyebabkan infeksi yang berulang, kekebalan tubuh yang berkurang dan status gizi semakin memburuk.

Hasil ini serupa dengan penelitian yang dilakukan oleh Azis, Kep Ns, (2018) menunjukkan dari 83 responden, diperoleh hasil responden yang mempunyai status gizi baik sebanyak 73 anak atau sebesar $88 \%$, gizi lebih sebanyak 4 anak atau sebesar 4,8\% dan gizi kurang sebanyak 6 anak atau sebesar $7,2 \%$.

Pendapat peneliti pola makanan yang baik untuk balita harus disesuaikan dengan usia balita sehingga tidak terjadi kelebihan atau kekurangan gizi.

\section{Gambaran Pemberian ASI Pada Balita}

Berdasarkan penelitian di Desa Sukamukti menunjukkan dari 150 balita yang diteliti, sebagian besar mendapatkan ASI eksklusif yaitu sebanyak 93 responden $(62,0 \%)$ dan sebanyak 57 responden ASI tidak eksklusif.

Menurut Roesli, (2000) ASI eksklusif adalah bayi hanya diberi ASI saja sampai bayi usia 6 bulan tanpa tambahan 
JOURNAL OF MIDWIFERY CARE :

VOL. 01 NO. 01, DESEMBER 2020

DOI: $\underline{10.34305 / J M C . V 1 I 1.197}$

cairan lain seperti susu formula, air jeruk, madu, air the, air putih dan tanpa bahan makanan padat seperti pisang, papaya, bubur susu, biskuit, bubur nasi dan tim.

Hasil penelitian ini serupa dengan penelitian yang dilakukan oleh Marselina, (2019), didapatkan hasil $\mathrm{p}<0,05(\mathrm{p}=0,000)$ sehingga dikatakan terdapat hubungan antara pemberian ASI dengan kejadian stunting di Kecamatan Cigandamekar Kabupaten Kuningan Tahun 2019.

Pendapat peneliti, pada umumnya ibu yang memiliki pengetahuan yang baik mengenai ASI akan memberikan ASI eksklusif bagi bayinya. Pendapat peneliti sejalan dengan penelitian dilakukan oleh Arifiati (2017), didapatkan nilai $\mathrm{p}<0,05$ $(\mathrm{p}=0,000)$ sehingga dikatakan terdapat hubungan yang signifikan antara pengetahuan ibu dengan pemberian ASI eksklusif.

\section{Gambaran Stunting Pada Balita}

Berdasarkan penelitian di Desa Sukamukti menunjukkan dari 150 responden yang diteliti, lebih dari setengahnya dalam kategori tidak stunting yaitu sebesar 79 responden $(52,7 \%)$ dan 71 responden mengalami stunting.

Stunting merupakan keadaan status gizi seseorang berdasarkan $\mathrm{z}$ score tinggi badan (TB) terhadap umur (U) dimana
Ciptaan disebarluaskan di bawah

Lisensi Creative Commons Atribusi-

NonKomersial-BerbagiSerupa 4.0

Internasional.

terletak pada <-2 SD.18 Tinggi badan dalam keadaan normal akan bertambah seiring bertambahnya umur. Pertumbuhan tinggi badan tidak seperti berat badan, relatif kurang sensitif terhadap masalah kekurangan gizi dalam waktu yang pendek. Pengaruh kekurangan zat gizi terhadap tinggi badan akan tampak dalam waktu yang relatif lama sehingga indeks ini dapat digunakan untuk menggambarkan status gizi pada balita.

Hasil penelitian ini serupa dengan penelitian yang dilakukan oleh Chairani (2019) menunjukkan hasil dari 92 balita yang diteliti sebanyak $61(66,3 \%)$ responden tidak mengalami stunting.

Peneliti berpendapat, pendidikan orangtua dapat membawa untuk memiliki ataupun meraih wawasan dan pengetahuan seluas-luasnya. Orang-orang yang memiliki pendidikan lebih tinggi akan memiliki wawasan dan pengetahuan yang lebih luas jika dibandingkan dengan orang-orang yang memiliki pendidikan yang lebih rendah. Hal ini dikarenakan orang tua yang memiliki pendidikan tinggi lebih mudah untuk menerima edukasi kesehatan selama kehamilan, misalnya dalam pentingnya memenuhi kebutuhan nutrisi saat. hamil dan pemberian ASI eksklusif selama 6 bulan, sehingga faktor pendidikan orang tua 
JOURNAL OF MIDWIFERY CARE :

VOL. 01 NO. 01, DESEMBER 2020

DOI: $\underline{10.34305 / J M C . V 1 I 1.197}$

memiliki peran terhadap stunting yang dialami balita.

\section{Perbedaan Status Gizi Pada Balita}

\section{Stunting dan Tidak Stunting}

Berdasarkan penelitian di Desa

Sukamukti menunjukkan pada balita dengan kecukupan nutrisi normal terdapat 46 balita $(55,9 \%)$ mengalami stunting dan pada balita dengan kecukupan nutrisi kurang terdapat 5 responden $(16,7 \%)$ mengalami tidak stunting, berdasarkan hasil Mann Whitney didapatkan nilai $\mathrm{p}$-value $=0,001$ lebih kecil dari $\square=0,05$ sehingga dapat diputuskan bahwa Ha diterima artinya ada perbedaan status gizi pada balita stunting dan tidak stunting di Desa Sukamukti Kecamatan Jalaksana Kabupaten Kuningan.

World Health Organization menguraikan penyebab stunting secara langsung dan tidak langsung. Secara langsung, penyebab kependekan berkaitan dengan empat faktor utama yaitu penyakit infeksi, praktik menyusui, ketersediaan makanan, serta lingkungan rumah tangga dan keluarga. Sementara secara tidak langsung, penyebab kependekan adalah faktor komunitas dan sosial yaitu ekonomi politik, kesehatan dan pelayanan kesehatan, pendidikan, sosial dan kebudayaan, pertanian dan sistem makanan, air, sanitasi dan lingkungan (Sundari et al, 2015).
Ciptaan disebarluaskan di bawah

Lisensi Creative Commons Atribusi-

NonKomersial-BerbagiSerupa 4.0

Internasional.

Sejalan dengan penelitian yang dilakukan oleh Damayanti (2016) pada balita dengan stunting dan tidak stunting di Kelurahan Kejawan Putih Tambak Kecamatan Mulyorejo Kota Surabaya, didapatkan hasil penelitian proporsi balita yang memiliki tingkat kecukupan energi inadekuat lebih banyak pada kelompok stunting $(54,5 \%)$ dan balita yang memiliki tingkat kecukupan energi inadekuat memiliki risiko stunting 9,5 kali lebih besar dibandingkan dengan balita yang memiliki tingkat kecukupan energi adekuat Penelitian ini didukung oleh penelitian dari Priyono (2015) status gizi balita stunting merupakan akumulasi dari kebiasaan makan terdahulu, sehingga pola pemberian makan pada hari tertentu tidak dapat langsung mempengaruhi status gizinya. Kunci keberhasilan dalam pemenuhan gizi terletak pada ibu. Kebiasaan makan yang baik sangat tergantung kepada pengetahuan dan keterampilan ibu akan cara menyusun makanan yang memenuhi syarat gizi (Suhardjo, 2010).

Penelitian Damayanti (2016) juga menyimpulkan bahwa balita yang memiliki tingkat kecukupan energi, protein, zinc, dan zat besi inadekuat memiliki risiko lebih besar untuk stunting (energi inadekuat $=9,5$ kali, protein inadekuat $=10.6 \mathrm{kali}$, zinc 
JOURNAL OF MIDWIFERY CARE :

VOL. 01 NO. 01, DESEMBER 2020

DOI: $\underline{10.34305 / J M C . V 1 I 1.197}$

inadekuat $=7,8$ kali, zat besi inadekuat $=3,2$ kali).

Pendapat peneliti, asupan makanan erat hubungannya dengan status gizi balita dan merupakan penyebab langsung terjadinya stunting. Mikhail (2013) kurangnya asupan energi dan protein menjadi penyebab gagal tumbuh. Kurangnya beberapa mikronutrien juga berpengaruh terhadap terjadinya retardasi pertumbuhan linear. Kekurangan mikronutrien dapat terjadi karena rendahnya asupan bahan makanan sumber mikronutrien tersebut dalam konsumsi balita sehari-hari serta disebabkan karena bioavailabilitas yang rendah (Mikhail et al., 2013). Meskipun balita tersebut mendapatkan cukup nutrisi masih bisa mengalami stunting, maupun sebaliknya balita yang mendapatkan asupan nutrisi kurang tidak mengalami stunting. Banyak faktor yang menyebabkan stunting tidak hanya asupan nutrisi saja melainkan terdiri dari beberapa faktor lainnya.

Perbedaan Pemberian ASI Pada Balita Stunting dan Tidak Stunting

Penelitian di Desa Sukamukti menunjukkan hasil pada 93 responden dengan pemberian ASI eksklusif terdapat 35 responden $(37,6 \%)$ mengalami stunting dan begitupun sebaliknya pada 57 responden
Ciptaan disebarluaskan di bawah

Lisensi Creative Commons Atribusi-

NonKomersial-BerbagiSerupa 4.0

Internasional

dengan riwayat ASI tidak eksklusif terdapat 21 responden $(36,8 \%)$ tidak mengalami stunting, berdasarkan hasil Mann Whitney didapatkan nilai $\mathrm{p}$-value $=0,002$ lebih kecil dari $\square=0,05$ sehingga dapat diputuskan bahwa Ha diterima artinya ada perbedaan riwayat ASI pada balita stunting dan tidak stunting di Desa Sukamukti Kabupaten Kuningan.

Astuti (2013) menjelaskan ASI eksklusif adalah pemberian ASI saja tanpa makanan pendamping apapun sampai bayi usia 6 bulan akan mempunyai manfaat yang luar biasa bagi perkembangan dan pertumbuhan bayi di samping itu dapat meningkatkan ikatan kasih sayang ibu dan anak.

Penelitian ini sejalan dengan penelitian yang dilakukan oleh Indrawati (2017) menunjukkan ada hubungan pemberian ASI eksklusif dengan kejadian stunting pada balita 2-3 tahun $\rho$-value $(0,000<0,05)$.

Peneliti berpendapat banyak faktor yang lebih kuat dan melatarbelakangi seorang anak mengalami stunting selain dari pemberian ASI. Menurut peneliti ASI merupakan asupan gizi yang sesuai dengan dengan kebutuhan akan membantu pertumbuhan dan perkembangan anak. Bayi yang tidak mendapatkan ASI dengan cukup 
JOURNAL OF MIDWIFERY CARE :

VOL. 01 NO. 01, DESEMBER 2020

DOI: $\underline{10.34305 / J M C . V 1 I 1.197}$
Ciptaan disebarluaskan di bawah

Lisensi Creative Commons Atribusi-

NonKomersial-BerbagiSerupa 4.0

Internasional berarti memiliki asupan gizi yang kurang baik dan dapat menyebabkan kekurangan gizi salah salah satunya dapat menyebabkan stunting. Sesuai dengan Prasetyono (2009) bahwa salah satu manfaat ASI eksklusif adalah mendukung pertumbuhan bayi terutama tinggi badan karena kalsium ASI lebih efisien diserap dibanding susu pengganti ASI atau susu formula. Sehingga bayi yang diberikan ASI Eksklusif cenderung memiliki tinggi badan yang lebih tinggi dan sesuai dengan kurva pertumbuhan dibanding dengan bayi yang diberikan susu formula. ASI mengandung kalsium yang lebih banyak dan dapat diserap tubuh dengan baik sehingga dapat memaksimalkan pertumbuhan terutama tinggi badan dan dapat terhindar dari risiko stunting.

\section{Kesimpulan}

Berdasarkan hasil penelitian terhadap 150 responden tentang perbedaan kecukupan nutrisi dan pemberian ASI pada balita stunting dan tidak stunting di Desa Sukamukti Wilayah Kerja UPTD Puskesmas Jalaksana Tahun 2020 maka dapat disimpulkan yaitu adanya perbedaan kecukupan nutrisi dan pemberian ASI pada balita stunting dan tidak stunting di Desa Sukamukti Wilayah Kerja UPTD Puskesmas Jalaksana Tahun 2020.

\section{Saran}

Ibu Menyusui diharapkan dapat meningkatkan pemberian ASI dan porsi makanan yang bergizi supaya tidak terjadi stunting.

\section{Daftar Pustaka}

Arifiati, N. (2017). Analisis Faktor Yang Mempengaruhi Pemberian Asi Ekslusif Pada Bayi Di Kelurahan Warnasari Kecamatan Citangkil Kota Cilegon. Prosiding Seminar Nasional IKAKESMADA "Peran Tenaga Kesehatan Dalam Pelaksanaan SDGs,"129-135.

Astuti, I. (2013). Determinan pemberian ASI eksklusif pada ibu menyusui. Jurnal Health Quality, 4(1), 1-76.

Azis, M. A., Kep, I. S., \& Ns, M. (2018). Gambaran Asupan Nutrisi Dan Status Gizi Balita Di Desa Joho Kecamatan Mojolaban Kabupaten Sukoharjo. Universitas Muhammadiyah Surakarta.

Chairani. (2019). Gambaran Pemberian ASI Eksklusif Terhadap Kejadian Stunting Pada Balita Umur 24-60 Bulan Di Kelurahan Tanah Baru Bogor tahun 2018. Promotor Jurnal Mahasiswa Kesehatan Masyarakat, 2(2).

Damayanti, R. A., \& Lailatul Muniroh, F. (2016). Perbedaan Pola Konsumsi Dan Riwayat Penyakit Infeksi Pada Balita Stunting Dan Non Stunting. Adi Husada Nursing Journal, 2(2), 61-68.

Danefi, T. (2019). Gambaran Pemberian Asi Eksklusif Pada Ibu Yang Memiliki Bayi Balita Stunting Di Desa Cikunir Tasikmalaya Tahun 2019. JURNAL 
JOURNAL OF MIDWIFERY CARE :

VOL. 01 NO. 01, DESEMBER 2020

DOI: $10.34305 / \mathrm{JMC} . \mathrm{V} 1 \mathrm{I1} .197$

KESEHATAN BIDKESMAS RESPATI, 2(10), 111-116.

Depkes, R. I. (2009). Profil Kesehatan Indonesia 2008. Jakarta: Departemen Kesehatan Republik Indonesia.

Dinas Kesehatan Kabupaten Kuningan. (2019). Profil Kesehatan Kuningan. inas Kesehatan Kabupaten Kuningan Jawa Barat.

Indrawati, S. (2017). Hubungan Pemberian ASI Esklusif Dengan Kejadian Stunting Pada Anak Usia 2-3 Tahun Di Desa Karangrejek Wonosari Gunungkidul. Universitas' Aisyiyah Yogyakarta.

Marselina, S. (2019). Hubungan pemberian ASI dengan kejadian stunting di Kecamatan Cigandamekar Kabupaten Kuningan Tahun 2019. Sekolah Tinggi Ilmu Kesehatan Kuningan.

Mikhail, W. Z. A., Sobhy, H. M., El-Sayed, H. H., Khairy, S. A., Abu Salem, H. Y. H., \& Samy, M. A. (2013). Effect of nutritional status on growth pattern of stunted preschool children in Egypt. Academic Journal of Nutrition, 2(1), 19.

Prasetyono, D. S. (2009). Buku pintar ASI eksklusif. Cetakan Pertama. Jogjakarta: Diva Press (Anggota IKAPI).

Priyono, D. I. P., Sulistiyani, S., \& Ratnawati, L. Y. (2015). Determinan Kejadian Stunting pada Anak Balita Usia 12-36 Bulan di Wilayah Kerja Puskesmas Randuagung Kabupaten Lumajang (Determinants of Stunting among Children Aged 12-36 Months in Community Health Center of Randuagung, Lumajang Distric).
Ciptaan disebarluaskan di bawah

Lisensi Creative Commons Atribusi-

NonKomersial-BerbagiSerupa 4.0 Internasional.

Pustaka Kesehatan, 3(2), 349-355.

Proverawati, A. (2013). Anemia Dan Anemia Kehamilan. Nuha Medika.

Riskesdas, K. (2018). Hasil Utama Riset Kesehatan Dasar (RISKESDAS). Hasil Utama Riset Kesehatan Dasar (RISKESDAS), 44.

Riskesdas, K. (2019). Hasil Utama Riset Kesehatan Dasar (RISKESDAS). Hasil Utama Riset Kesehatan Dasar (RISKESDAS), 44.

Roesli, U. (2000). Mengenal ASI eksklusif. Niaga Swadaya.

Suhardjo, K. C. M. (2010). Principles of Nutritional Science (Prinsip-prinsip Ilmu Gizi). Yogyakarta: Kanisius.

Sundari, D., Almasyhuri, A., \& Lamid, A. (2015). Pengaruh proses pemasakan terhadap komposisi zat gizi bahan pangan sumber protein. Media Litbangkes, 25(4), 235-242.

WHO. (2017). Obesity and Overweight. 